\title{
SzABó Szilárd \\ Az osztrák-magyar katonai hírszerzés \\ szervezeti és hatásköri változásai az I. világháború idején
}

(Organizational and Functional Changes

in the Austro-Hungarian Military Intelligence Service during WWI)

Absztrakt

Az osztrák-magyar katonai hírszerző szolgálat fejlődése — a vezérkari főnöknek alárendelt Nyilvántartó Iroda által létrehozott alapokra támaszkodva - az I. világháború idejére esett. Ezen időszak alatt vált az Osztrák-Magyar Monarchia hírszerző szolgálat professzionális hírszerző és elhárító szervezetté. A Nyilvántartó Iroda (Evidenzbureau) a háború kitörésekor betagolódott a Haderő-föparancsnokság (Armeeoberkommando) szervezetébe, mint annak hírszerző részlege (Nachrichtenabteilung). Ez a szervezet képezte az I. világháború alatt a dualista államalakulat teljes katonai hírszerzés és elhárítás központját. Elsősorban a rejtjelfejtő-részleg(ek) épültek ki, ugyanakkor a hírszerző-elhárító és az elemző-kiértékelő funkció szervezetileg nem vált külön, ellentétben például a német katonai hírszerző szolgálat (Nachtrichtenbureau) gyakorlatával.

Kulcsszavak

Osztrák-Magyar Monarchia ； I. világháború ； hírszerző szolgálat ； Nyilvántartó Iroda ； haderő-főparancsnokság

Abstract

Improvement of the Austro-Hungarian military intelligence service - supported by a foundation established by the Directorate of Military Intelligence (Evidenzbureau), which was under the command of the Chief of Staff - occurred during WWI. At this time the Austro-Hungarian military intelligence service became a professional intelligence and counterintelligence organization. At the outbreak of the war, the Evidenzbureau was absorbed by the Army Higher Command (Armeeoberkommando) as its intelligence section (Nachrichtenabteilung). This organization formed the hub of all military intelligence and counterintelligence of the Dualist State during the entirety of WWI. The cryptography section(s) was (were) set up first, even as counterintelligence and analysis/evaluation functions were organizationally not separated, which, for example, went against the practices of the German military intelligence service (Nachtrichtenbureau)

Key words

Austro-Hungarian Monarchy ； World War I ； intelligence service ； Directorate of Military Intelligence ;

Army Higher Command

A

z I. világháború kitörése után az Osztrák-Magyar Monarchia katonai hírszerző szolgálatának központi szervét alkotó Evidenzbureau (Nyilvántartó Iroda, a továbbiakban Iroda) szinte kiürült, mivel az állomány nagy része a szárazföldi Haderő-fơparancsnokság hírszerző részlegéhez (Nachrichtenabteilung des Armeeoberkommandos, a továbbiakban AOK Nabt.) kerültt. ${ }^{1}$ A megmaradt állomány formálisan a közös hadügyminisztérium illetve a vezérkari fönök helyettese alárendeltségébe tartozott ugyan, azonban tulajdonképpen az AOK Nabt részeként müködött (Rücklass-Abt. der Nabt) mint az AOK Nabt egyfajta kiegészítője és Bécsben folytatta tovább tevékenységét. ${ }^{2}$ Ide tartozott az angol és francia nyilvántartó csoport (Evidenzgruppe), a kódfejtő csoport, valamint az erődítési és a tüzérségi csoport, amelyeket 1915. I. 1-én összevontak, majd 1915. VII. 1-töl már csak tüzérségi csoport néven folytatta tovább müködését. ${ }^{3}$ 1916. I. 1-én létrehozták a politikai csoportot, az angol nyilvántartó csoportot pedig összevonták a némettel. A politikai csoport elsődleges feladata a kémelhárítás, a „külföldi hazaárulók" nyilvántartása és a rájuk vonatkozó információk továbbítása azon szervek felé, akik azután nyomon követték az ,államellenes cselszövéseket” (staatsfeindliche Umtriebe). ${ }^{4}$

1916. IX. 1-én a kódfejtő csoportot két részre bontották: a Chiffregruppe I. foglalkozott ezután az idegen kódolt üzenetek feltörésével, majd 1918. VII. 1-től különleges rendelkezések alapján végezte a kódolt üzenetek összegyüjtését és csoportosítását. A Chiffregruppe II. 1918. VII. 1-ig a saját üzenetek kódolását, majd a semleges és szövetséges államok üzeneteinek dekódolását végezte. Albert PETHÖ szerint a Chiffregruppe I. hatáskörébe a francia, az angol és a diplomáciai rádióforgalom lehallgatása tartozott, POKORNY Hermann vezérezredes visszaemlékezéseiben pedig azt olvashatjuk, hogy „az I-ben a központi rádióállomásokon lehallgatott táviratokat desifrírozták, a II-ben a közvetlen távíróvonalak lehallgatása folyt". ${ }^{5}$ 1917. II. 1-vel az olasz, orosz és Balkán csoportot feloszlatták.

$*$

Open Researcher and Contributor ID = Nyílt Kutató és Közremüködő Azonosító (ORCID) : https://orcid.org/0000-0003-0665-2424

Institutional attachements $=$ Szerző intézményi kötődései :

- Bertalan Szemere Scientific Society of History of Hungarian Law Enforcement = Szemere Bertalan Magyar Rendvédelem-történeti Tudományos Társaság

- University of Debrecen, Faculty of Humanities, Department of Politi- = Debreceni Egyetem Bölcsészettudományi Kar Politikatudományi és Szocical Science and Sociology lógiai Intézet.

- Hungarian Historical Society

= Magyar Történelmi Társulat 
Ezután az Iroda a következő csoportokból állt: a politikai, az angol, a francia, a tüzérségi, a személyzeti csoport (Manipulationsgruppe), valamint a két kódfejtő csoport. Ekkor két új csoportot is létrehoztak, az elhárító és a propaganda csoportot. ${ }^{6}$ 1917. V. 15-től az első kódfejtő csoport (a Chiffregruppe I.) két részre bomlott: egy olasz és egy francia csoportra. ${ }^{7}$ 1917. IV. 10-én Károly ausztriai császár és magyar király Maximilian RONGE ezredest nevezte ki az AOK Nabt és így az Iroda fónökévé. ${ }^{8}$ Az Iroda operatív irányítását 1918 februárjától POKORNY Hermann alezredes látta el. ${ }^{9} 1917$. IV. 12-én az addig AOK Nabt keretében müködö összes nyilvántartó csoportot megszüntették és 1917. XI. 1-ei hatállyal az Iroda szervezetébe illesztették. ${ }^{\mathbf{1 0}}$

Az utolsó átszervezésre 1918. III. 30-i hatállyal került sor. Ekkor alakult meg az adjutánsi iroda és kezdte meg müködését a belföldi csoport („Inlands-Gruppe”). A háború végén, 1918 novemberében az Iroda a következő csoportokból szerveződött: politikai, elhárító, tüzérségi és erődítési, nyilvántartó, belföldi, két kódfejtő csoport, a személyzeti csoport, valamint az un. zsákmány csoport („Beute-Gruppe”) illetve 1 fö különleges feladatokra. ${ }^{11}$

Az Iroda szervezetében müködő csoportoknál is lezajlott az a folyamat, ami korábban a hírszerző csoportnál is megfigyelhető, vagyis ezek a csoportok is egyre jobban tagolódtak, egyre több, különböző feladatokat ellátó alcsoportokra, referatúrákba szerveződtek. Az elhárító csoportban hat referatúra müködött: szervezési, nyilvántartó, egy külön referatúra, mely más szervekkel tartotta a kapcsolatot, egy jogi ügyekkel foglalkozó, egy a körözésekkel és más különleges feladatokkal foglalkozó és egy az AOK Nabt felderítő csoportjaival kapcsolatot tartó referatúra. A politikai csoport 1918. VII. 1-ig szintén hat referatúrából állt: cseh, lengyel és ukrán, délszláv, magyar és román, olasz és egy nemzetközi mozgalmakkal foglalkozó referatúrából.

1918. VII. 1. után kezdte meg tevékenységét a politikai hírszerző referatúra, a cseh referatúra kibővült a német ügyekkel, a magyar és román referatúra pedig ezután csak a román ügyekkel foglalkozott, a magyarokkal már nem foglalkoztak. Az Iroda nyilvántartó csoportja két osztályra bomlott. Az Evidenzgruppe I. három referatúrából állt, egy Nagy-Britanniával és annak gyarmataival, egy Egyesült Államokkal és Ázsiával, valamint egy Németországgal és a tengeralattjáró-háborúval foglalkozó referatúrából, amihez tartozott az Iroda könyvtára is. Az Evidenzgruppe II. két referatúrát foglalt magába: egy Franciaországgal, Belgiummal és azok gyarmataival foglalkozót és egy Spanyolországgal, Portugáliával azok gyarmataival, valamint Közép- és Dél-Amerikával foglalkozó referatúrát. ${ }^{12}$

A XX. század elejétől a hírszerző tevékenység irányítója a felderítő csoport (Kundschaftsgruppe) volt. ${ }^{13}$ 1907-ben, amikor Maximilian RONGE átvette a csoport irányítását a kémtevékenység súlypontja a Balkán, különösen Szerbia volt. Az Iroda akkori fönöke Eugen HoRDLICZKA ezredes a prioritást erre a területre helyezte és az Oroszország elleni hírszerző munka csak minimális erővel folyt. ${ }^{14}$

Ami az Iroda elhárító funkcióját illeti, ezt kezdetben a Kundschaftsgruppe látta el. ${ }^{15}$ 1917-ben kivált belőle és külön csoporttá szerveződött a védelmi csoport (Defensivgruppe), ami hat referatúrára tagolódott. ${ }^{16}$ Emellett a politikai csoport is túlnyomórészt elhárító funkciót látott el. ${ }^{17} \mathrm{Az}$ 1917. X. 19-ei Ressorteinteilung alapján az Iroda elhárító csoportjának fönöke felelt a kémelhárítás megszervezéséért, az ő dolga volt a nagyobb jelentőségủ feladatok elvégzése, az elhárítás érdekképviselete a különböző megbeszéléseken és a többi részleggel való kapcsolattartás, szakértőként való részvétel nagyobb kémperekben és a csoport pénzügyeinek ellenőrzése.

Az első referatúra hatáskörébe az elhárítás szervezési részfeladatai, a jelentéstétel szabályozása, a katonai titkok védelmének megszervezése, a csendőrség, a leszerelés és a napló vezetése, valamint a katonai elhárítás, az államrendőrség és a szövetséges államok elhárítási szervezetének nyilvántartása tartozott. A 2. referatúra vezette a nyilvántartást az ellenséges kémhálózatról és kémelhárításról, segédleteket készített az ellenséges hírszerzőszolgálatok felépítéséről, konkrét javaslatokkal kellett elóállnia az ellenséges kémtevékenység letörésére és a szabotázsakciók elleni védekezés is ide tartozott.

A 3. referatúra hatásköre kiterjedt a posta, távíró és telefonszolgáltatás területére vonatkozó kémelhárításra, a levelek, táviratok, sürgönyök és csomagok átkutatására, (cenzúra) a titkosírásra, a határ és útellenőrzésre, az Osztrák-Magyar Monarchián belüli forradalmi mozgalmak nyilvántartására, valamint a vegyi laboratórium vezetésére. A 4. referatúra intézte a kémkedési ügyekkel összefüggő jogi eljárásokat, előkészítette az erre vonatkozó törvényeket, az elhárítás szempontjából felügyelte a sajtót és ide tartoztak a hadifoglyokkal kapcsolatos ügyek is. ${ }^{18} \mathrm{Az} 5$. referatúra foglalkozott a kémgyanús elemek körözésével, a velük kapcsolatos információk cseréjével, idegen tisztek beutazásával kapcsolatos ügyekkel, a belső elhárítással, illetve a fotókkal. Végül a 6. referatúra tartotta a kapcsolatot a Nabt felderítő csoportjaival. ${ }^{19}$ 
A politikai csoport vezetője hatáskörébe tartozott a politikai hírszerzés megszervezése az elhárító csoport segítségével, új hírszerzési források közzététele, közlése, elvi jellegü kérdések tisztázása, tanácsadás alkotmány, közigazgatási, és nemzetközi jogi ügyekben, katonai szakértőként való közremüködés a csoport feladatkörét érintö ügyekben, illetve a csoport képviselete. A csoportvezető különleges esetben olyan feladattal is megbízhatott egy referatúrát, amely eredetileg nem tartozott a hatáskörébe. 1918. VII. 1-től a csoportvezető saját hatáskörében dönthetett a feladatok kiosztásáról, továbbá az ö dolga lett az egyes referatúrák munkájának összehangolása, a munkálatok végrehajtási módozataira történő konkrét utasítások kibocsátása, valamint a referatúrák jelentéseinek felülvizsgálata. Magának a csoportnak a feladata az egyes nemzeti mozgalmak, különösen a szocialista, cionista, szabadkőmüves, adventista mozgalmak, azon belül a vezető pártok, szervezetek és sajtóorgánumok figyelemmel kísérése, a békekötéssel kapcsolatos kérdések, valamint gazdaságpolitikai természetủ jelentések. ${ }^{20}$

\section{A Nachrichtenabteilung des Armeeoberkommandos AOK Nabt (Szárazföldi Haderő Főparancs- nokság hírszerző részlege) 1914-1918}

A mozgósításra vonatkozó előírásoknak megfelelően állították fel az AOK hírszerző részlegét. Az AOK Nabt hatáskörébe tartozott a katonai hírszerzés és az ellenséges haderőkről vezetett nyilvántartás legmagasabb szintü irányítása. Tulajdonképpen először a balkáni hírszerző részleg (Nachrichtenabteilung Balkan) került felállításra az Balkáni Haderők Főparancsnoksága (Oberkommando der Balkanstreitkräfte) részeként. Ebből vált ki az orosz hírszerző részleg (Nachrichtenabteilung Russland), ami a Keleti Főparancsnokság (Ost-Oberkommando OOK) részeként 1914. VIII. 16-17-én Przemyšlbe települt. ${ }^{21} \mathrm{Az}$ Iroda állományából 17 tiszt került át az AOK Nabt állományába. ${ }^{22} \mathrm{Az}$ AOK Nabt és az Iroda eleinte egységesen Oskar HRANILOVIC von CZVETASSIN ezds. vezetése alatt maradt, aki így a harctéri hírszerzésért is felelt. ${ }^{23}$ Azonban már 1914. VIII. 19-én Maximilian RonGÉt bízták meg a Nabt hírszerző és elhárító tevékenységének irányításával. ${ }^{24}$

1915. I. 1-én a Nabt már rendelkezett politikai és propaganda referenssel, szeptemberben pedig felállították a Nabt sajtóosztályát, melynek fő feladata a külföldi sajtó figyelése és a semleges országok sajtójából jelentés összeállítása volt. ${ }^{25}$ Emellett a Nabt szervezete egy Balkán, egy tolmács, egy erődítési és egy külön hírszerző csoportra tagolódott. Ezen kívül egy személyzeti csoport (Manipulationsgruppe) tartozott hozzá, valamint volt egy képviselőjük a közös külügyminisztériumnál. A kezdeti létszám (17 tiszt) 1916-ig nem nagyon növekedett, ekkor 20 tiszt alkotta a Nabt állományát. A Nabt állományában 1917 elején még mindig csak 29 tiszt teljesített szolgálatot. 1917. I. 1-től az AOK egy szemantikai jellegü változtatást is véghezvitt, a Kundschaftsdienst elnevezés helyett a Nachrichtendienst kifejezést használta. Ennek megfelelően változtak meg a Kundschaftsstellen és a Kundschaftsoffiziere szavak is Nachrichtenstellen illetve Nachrichtenoffiziere kifejezésekre. ${ }^{26}$

A Nabt ekkor a katonai hírszerzés vezetöjét Oskar HRANILOVIC von CZVETASSIN-t, helyettesét, a Nabt hírszerző és elhárító tevékenységének irányítóját Maximilian RONGE-t, a helyettes vezetése és irányítása alatt álló offenzív és defenzív hírszerzö-elhárító csoportokat (Kundschaftsgruppen) az orosz, olasz és a Balkán -csoportot, és a politikai csoportot foglalta magában, valamint hozzátartozott még a személyzeti csoport (Manipulationsgruppe) és egy regisztrátor is. Az orosz, olasz és a Balkán-csoport úgynevezett Evidenzgruppe volt, vagyis az illető államok haderejéröl vezetett nyilvántartást. ${ }^{27}$

1917. III. 25-től Oskar HRANILOVIC von CZVETASSIN ezds. fokozatosan átadta a Nabt irányítását Maximilian RoNGÉnak. Ez egyben az Iroda és a Nabt fokozottabb önállósodását is eredményezte. ${ }^{28} \mathrm{Az}$ 1917. IV. 7-én kelt 7000. számú rendelkezés határozta meg ezután a Nabt felépítését. A Nabt személyi állománya ekkor 29 tisztből és hivatalnokból állt. ${ }^{29} 1917$ végén az immáron Maximilian RONGE vezetése alatt álló Nabt (székhelye: Baden) jelentősen kibővült, összesen hat csoport, azon belül nyolc alcsoport alkotta. Az I. csoport volt az un. „Erkundungsgruppe”, amely aktív felderítö, hírszerző tevékenységet (Offensiver Dienst) látott el. Ennek a csoportnak 5 osztálya, alcsoportja müködött, nevezetesen az I. a. az orosz, az I. b. az olasz, az I. c. a Balkán, az I. d. az un. „Inlandgruppe”, valamint az I. e. az un. békepropaganda referatúra.

Közülük az elhárító feladatokat (Defensiver Dienst) I. d. osztály végzett. A rejtjel-csoport (Die Kriegs-Chiffregruppe), azaz II. csoport, aminek vezetője POKORNY Hermann volt végezte a kódolást és kódfejtést. Ide tartozott az olasz a II./a., a román a II./b. és az orosz a II./c. alcsoport. A személyzeti a III. csoport, az útlevél a IV., a skandináv az V. csoport — ami később átkerült az Iroda szervezetébe , végül a személyzeti (Manipulationsgruppe) a VI. csoport volt. Az útlevél csoport — amelynek vezetöje kivételesen nem katona, hanem rendőr volt — szintén elhárító feladatokat végzett. ${ }^{30}$ Bár nem alkotott külön csoportot a tolmácsszolgálat, mégis a Nabt keretén belül maradt. ${ }^{31}$ 
1918. I. 1-én az AOK Nabt szervezete Maximilian RONGE vezetése alatt annyiban változott, hogy az Erkundungsgruppe már csak 4 alcsoportból állt, mivel a békepropaganda referatúra megszünt, a rejtjelcsoporton belül pedig a román helyett ekkor már Balkán alcsoport múködött. Ezen kívül az Iroda szervezetében egy Nabt összekötő tiszt teljesített szolgálatot. 1918. VII. 1-től az Erkundungsgruppe osztályai önállókká váltak. Emellett a Nabt egy tisztjét a közös külügyminisztérium útlevélközpontjához osztották be, létrehoztak egy tolmácsiskolát és egy különálló útlevélhivatalt. ${ }^{32}$

Az AOK Nabt képezte az I. világháború alatt a teljes katonai hírszerzés és elhárítás központját. A Nabt szervezetén belül is a legfontosabb funkciót az Erkundungsgruppe és a rejtjelcsoport látta el, mivel az általuk szerzett információk alapján döntött a legfelsőbb katonai vezetés a legfontosabb stratégiai kérdésekben. ${ }^{33}$ Úgy is fogalmazhatunk, hogy a Nabt egyfajta döntés-elökészítő funkciót is ellátott, de legalább ilyen fontos volt, hogy ellenőrizze az AOK döntéseinek végrehajtását. ${ }^{34}$ Ezt a funkciót az Osztrák-Magyar Monarchia országai, illetve az elfoglalt területeken felállított hírszerző állomások és az ott szolgálatot teljesítő mintegy 2500 tiszt és hivatalnok révén valósította meg. ${ }^{35}$ Mellettük az AOK Nabt számíthatott azokra a személyekre, akik üzletszerüen foglalkoztak hírszerző tevékenységgel (Kundschafter), valamint azokra, akik szolgálataikért cserébe nem számíthattak díjazásra, legfeljebb a költségeik megtérítésére voltak jogosultak, esetleg alkalomszerúen részesülhettek valamilyen ellenszolgáltatásban (Berichterstatter), végül azon személyek szolgálataira, akik kizárólag hazafias érzületből, ellenszolgáltatás nélkül folytattak kémtevékenységet (Vertrauensmann). ${ }^{36}$

Az I. világháború alatt az osztrák-magyar katonai hírszerzés egyre magasabb színvonalon látta el feladatát. Maximilian RONGE némileg elfogult véleménye szerint „Daß vielleicht in keinem Krieg so eingehende und zutreffende, und was besonders wichtig ist, rechtzeitige Daten über die feindlichen Maßnahmen erlangt wurden" [Talán még egy háborúban sem végeztek olyan alapos és pontos hírszerző tevékenységet, mint amit az Osztrák-Magyar Monarchia hírszerzői végeztek.] ${ }^{37}$ Az I. világháború folyamán az információszerzés elsődleges forrásává egyértelmủen a telefonok és távírók lehallgatása, a rejtjelezett küldemények megfejtése vált. Ezért kulcsfontosságú volt a rádióadások és telefonvonalak lehallgatása, valamint az, hogy ki irányítja, ki felügyeli ezt a területet. 1917 elején Maximilian RoNGE megakadályozta, hogy Rudolf SCHAMSCHULA vörgy., a távírószolgálat fönöke magához vonja a rejtjelcsoportot, a tolmács- és a rádiólehallgató-szolgálatot. Azonban 1917 októberében az AOK hadmüveleti osztálya magához vonta a keleti és a délnyugati front rádiólehallgató-szolgálatát. Mivel ez a változtatás nem bizonyult hatékonynak, 1918 júniusában visszaállították az eredeti rendszert, vagyis az irányítás és a felügyelet visszakerült a Nabt szervezetébe. ${ }^{38}$

\section{Jegyzetek:}

${ }^{1}$ ÖSA.KA. Nachlässe und Sammlungen. [Hagyatékok és gyüjtemények.] Nachlaß Ronge. [RoNGE hagyaték.] Nachrichtenabteilung des Armmeoberkommandos im Weltkrieg 1914-1918. [A Szárazföldi Haderő Főparancsnokság Hírszerző Részlege a Világháborúban 1914-1918.] B. u. C./126. 1.p.

${ }^{2}$ Loc.cit. 2.p. ; RONGE

3 - ÖSA.KA. op.cit. Nachlässe und Sammlungen. [Hagyatékok és gyüjtemények.] Nachlaß Ronge. [RonGE hagyaték.] Geschichte des Evidenzbureaus des Generalstabes. [A Vezérkar Nyilvántartó Irodájának története.] B. u. C./126. 238-239.p.

- REIFBERGER: 218.p.

- РЕTHÖ: 57-58.p.

${ }^{4}$ SCHEER: 63.p.

5 - ÖSA.KA. op.cit. Nachlässe und Sammlungen. [Hagyatékok és gyüjtemények.] Nachlaß Ronge. [RonGE hagyaték.] Ressorteinteilung. [Hatásköri beosztás.] B. u. C./126.

- РЕTHÖ: op.cit. 128.p.

- POKORNY

${ }^{6}$ - ÖSA.KA. op.cit. Armeeoberkommando. Evidenzbüro Karton 3649. Offiziers-Einteilungslisten Ende August - 1916 August 1918. Österreichisches Staatsarchiv Kriegsarchiv, Armeeoberkommando Evidenzbüro Karton 3649. Offiziers-Einteilungslisten Ende August 1916 - August 1918. [Osztrák Állami Levéltár, Hadilevéltár, Szárazföldi Haderő Főparancsnoksága, Nyilvántartó Iroda, 3649. számú doboz, 1916 augusztusa és 1918 augusztusa közötti tiszti beosztások.]

A lista adatai kissé félrevezetők, abból a szempontból, hogy nem azt tartalmazzák, melyik tiszt mikor került az adott csoport kötelékébe, hanem azt, hogy az adott tiszt mikor lépett az Irodaszolgálatába. Vagyis ez a Kriegsarchivban található táblázat nem ad pontos felvilágosítást arra vonatkozóan, hogy az adott csoport mikor alakult meg. Az viszont kiderül belőle, hogy az Iroda Balkán, olasz és orosz csoportjaiban legkésőbb 1917 januárjától már senki sem szolgált.

- ÖSA.KA. op.cit. Nachlässe und Sammlungen. [Hagyatékok és gyüjtemények.] Nachlaß Ronge. [RoNGE hagyaték.] Geschichte des Evidenzbureaus des Generalstabes. [A Vezérkar Nyilvántartó Irodájának története.] B. u. C./126. 240-241.p. Pethö könyvében politikai és sajtócsoport szerepel, amit szerinte 1915 áprilisában hoztak létre.

- РЕTHÖ: op.cit. 58.p. + 258.p. 
${ }^{7}$ ÖSA.KA. op.cit. Nachlässe und Sammlungen. [Hagyatékok és gyüjtemények.] Nachlaß Ronge. [RongE hagyaték.] Geschichte des Evidenzbureaus des Generalstabes. [A Vezérkar Nyilvántartó Irodájának története.] B. u. C./126. 240-242.p.

8 - ÖSA.KA. op.cit. Nachlässe und Sammlungen. [Hagyatékok és gyüjtemények.] Nachlaß Ronge. [RoNGE hagyaték.] Nachrichtenabteilung des Armmeoberkommandos im Weltkrieg 1914-1918. [A Szárazföldi Haderö Főparancsnokság Hírszerző Részlege a Világháborúban 1914-1918.] B. u. C./126. 36.p.

- RONGE: op.cit. 274-276.p.

${ }^{9}$ Tulajdonképpen már 1917 októberétől ő vezette az Irodát, de munkáját még nem tudta megkezdeni, mert részt vett a bresztlitovszki béketárgyalásokon. POKORNY Hermann 1882. IV. 7-én született a morvaországi Kremsier (Kromeriz) városában német nemzetiségủ családban. 1901-ben avatták hadnaggyá, 1910-ben százados, 1915-től őrnagy. 1918 novemberében még magyar állampolgársága megszerzése elött átveszi a magyar királyi honvédség. Itt lesz 1921-ben ezredes és innen megy nyugállományba 1935-ben, mint altábornagy. 1945 februárjában az Ideiglenes Nemzeti Kormány reaktiválja, október 6-án vezérezredessé léptetik elő és 1949-ig a Külügyminisztériumban teljesít szolgálatot. 1960-ban Budapesten hunyt el.

POKORNY: op.cit.

10 - ÖSA.KA. op.cit. Nachlässe und Sammlungen. [Hagyatékok és gyüjtemények.] Nachlaß Ronge. [RonGE hagyaték.] Geschichte des Evidenzbureaus des Generalstabes. [A Vezérkar Nyilvántartó Irodájának története.] B. u. C./126. 244.p.

- ÖSA.KA. op.cit. Nachlässe und Sammlungen. [Hagyatékok és gyüjtemények.] Nachlaß Ronge. [RoNGE hagyaték.] Nachrichtenabteilung des Armmeoberkommandos im Weltkrieg 1914-1918. [A Szárazföldi Haderő Főparancsnokság Hírszerző Részlege a Világháborúban 1914-1918.] B. u. C./126.36.p.

11 - ÖSA.KA. op.cit. Nachlässe und Sammlungen. [Hagyatékok és gyüjtemények.] Nachlaß Ronge. [RonGE hagyaték.] Geschichte des Evidenzbureaus des Generalstabes. [A Vezérkar Nyilvántartó Irodájának története.] B. u. C./126. 244-246.p.

1917 októberében még volt un. skandináv csoport, amelyben Svédországgal, Dániával és Norvégiával foglalkoztak. Ezt a csoportot azonban a háború végére a nyilvántartó csoportba tagolták.

- ÖSA.KA. op.cit. Nachlässe und Sammlungen. [Hagyatékok és gyüjtemények.] Nachlaß Ronge. [RoNGE hagyaték.] Resorteinteilung. B. u. C./126.

- PETHŐ: op.cit. 59.p.

12 Loc.cit.

${ }^{13}$ Urbanski: 887.p. ; PetHÖ: op.cit. 20.p. ; SCHÄTZ: 97.p.

${ }^{14}$ MORITZ - LEIDINGER - JAGSCHITZ : 69.p.

${ }^{15}$ KA.NS. Nachlaß Urbanski [URBANSKI hagyatéka] B/58. „Das Tornisterkind. Lebenserinnerungen des Feldmarschalleutnant von Urbanski”. [A hátizsákos fiú. URBANSKI altábornagy emlékiratai.] 66.p.

${ }^{16}$ „Egyes tisztek elmeséléséböl értesültem, hogy ott a cél érdekében (állam vagy párt védelme) eszközeikben cseppet sem voltak válogatósak. Minden lelki és testi kínzást alkalmaztak, mely a célhoz vezetett. Az volt a benyomásom, hogy erre a szolgálatra csak erkölcsileg romlott, minden gazságra képes egyének alkalmasak".

POKORNY: op.cit.

${ }^{17}$ Feladata többek között az állam és hadseregellenes propaganda összegyüjtése, értékelése, illetve jelentéstétel a civil és katonai hatóságok számára. Ezek a jelentések gyakran képezték parlamenti interpellációkra adott válaszok alapját.

ÖSA.KA. op.cit. Nachlässe und Sammlungen. [Hagyatékok és gyüjtemények.] Nachlaß Ronge. [RoNGE hagyaték.] Ge-schichte des Evidenzbureaus des Generalstabes. Tätigkeit des Evidenzbureaus des Generalstabes. Beitrag der P. Gruppe. [A Vezérkar Nyilvántartó Irodájának tevékenysége. A P[olitikai]. csoport melléklete.]

${ }_{18}^{18}$,A hadifogolyposta cenzúrája. Ez a hivatal a belvárosban volt elhelyezve, nagy személyzettel rendelkezett, nyelvtudósokkal, írásszakértökkel, rajzolókkal, vegyészekkel, valamint egy jól felszerelt laboratóriummal. Feladata az volt, hogy a hadifoglyokhoz beérkezö és tölük feladott levelezést cenzúrázza. Ezek az orosz és az olasz hadseregre, az ország hangulatára, valamint az ellenséges csapattestek tábori postaszámaira vonatkozó minden adatot nyilvántartottak. A kívánatos adatok beszerzése céljából a feladott levelezölapokat írásszakértők megfelelö kérdésekkel egészitették ki, vagy új lapokat hamisitottak.". POKORNY: Emlékeim.

POKORNY: op.cit.

19 - ÖSA.KA. op.cit. Nachlässe und Sammlungen. [Hagyatékok és gyüjtemények.] Nachlaß Ronge. [RongE hagyaték.] Resorteinteilung. B. u. C./126.

${ }^{20}$ 1918. VII. 1-től felállítottak egy K jelzésủ referatúrát, amely a pénztárral, a fotókkal, a naplóvezetéssel és a Nabt-tal való kapcsolattartással lett megbízva. Nachlaß Ronge. Ressorteinteilung. „Irodámhoz többféle osztály tartozott: 1. a velünk nem közvetlenül harcban álló és a semleges hadseregek nyilvántartása; 2. a politikai nyilvántartás, az államellenes megmozdulások és ezekben az exponált személyek nyilvántartása. Amikor a megbizhatatlan csehek lajstromát megláttam, feltettem a kérdést, hogy nem volna-e egyszerübb a megbizhatókról egy vékony füzetet tartani. Ehhez az osztályhoz tartoztak az osztrák parlamentböl kapott információk, melyeket a rendörség egyik bizalmas közege juttatott el. Megjegyzem, hogy egyszer, mint nézö, végig figyeltem egy parlamenti ülést. A kiabálások, dühkitörések, a fegyelmezetlen viselkedés és a képviselök modora undoritó látványt nyújtottak;".

POKORNY: op.cit.

21 - ÖSA.KA. op.cit. Nachlässe und Sammlungen. [Hagyatékok és gyüjtemények.] Nachlaß Ronge. [RoNGE hagyaték.] Nachrichtenabteilung des Armmeoberkommandos im Weltkrieg 1914-1918. [A Szárazföldi Haderő Főparancsnokság Hírszerző Részlege a Világháborúban 1914-1918.] B. u. C./126. 1.p.

- PETHÖ: op.cit. 57.p. ; ZeINAR: 560.p.

22 RONGE: op.cit. 92-93.p.

${ }^{23}$ Loc.cit. ; PETHÖ: op.cit.

24 - ÖSA.KA. op.cit. Nachlässe und Sammlungen. [Hagyatékok és gyüjtemények.] Nachlaß Ronge. [RoNGE hagyaték.] Nachrichtenabteilung des Armmeoberkommandos im Weltkrieg 1914-1918. [A Szárazföldi Haderö Főparancsnokság Hírszerző Részlege a Világháborúban 1914-1918.] B. u. C./126. 2.p.

${ }^{25}$ Loc.cit. 8.p. + 17.p. 
26 - HHStA. Schaffung einer Zentralstelle für den defensiven Kundschafterdienst [Az elhárító szolgálat központi állomásának felállítása.] 2616/M. I. Abschrift, Wien, 26. 02. 1917. Spionageabwehrdienst. [Kémefelderítő szolgálat.] 1913-1917, PA XL Interna LI/6. Karton 242.

- РЕTHÖ: op.cit. 57-58.p. + 82.p.

${ }^{27}$ ÖSA.KA. op.cit. Nachlässe und Sammlungen. [Hagyatékok és gyüjtemények.] Nachlaß Ronge. [RonGE hagyaték.] Nachrichtenabteilung des Armmeoberkommandos im Weltkrieg 1914-1918. [A Szárazföldi Haderő Főparancsnokság Hírszerző Részlege a Világháborúban 1914-1918.] B. u. C./126.31.p.

- РетHÖ: op.cit. 58.p.

${ }^{28}$ ÖSA.KA. op.cit. Nachlässe und Sammlungen. [Hagyatékok és gyüjtemények.] Nachlaß Ronge. [RoNGE hagyaték.] Nachrichtenabteilung des Armmeoberkommandos im Weltkrieg 1914-1918. [A Szárazföldi Haderő Főparancsnokság Hírszerző Részlege a Világháborúban 1914-1918.] B. u. C./126. 36.p.

${ }^{29}$ Loc.cit.41.p.

${ }^{30}$ A Balkán — csoport vezetője 1917. IV. 7-től a háború befejezéséig — STOJAKOvITs Demeter (1883-1946) volt. 1935-ben SzTÓJAY Döme néven altábornagy, 1936-1944 között berlini magyar követ, 1944. III. 22. és VIII. 29-e között magyar királyi miniszterelnök. 1946-ban háborús bünök vádjával elítélték és kivégezték.

- ÖSA.KA. op.cit. Nachlässe und Sammlungen. [Hagyatékok és gyüjtemények.] Nachlaß Ronge. [RonGE hagyaték.] Nachrichtenabteilung des Armmeoberkommandos im Weltkrieg 1914-1918. [A Szárazföldi Haderő Főparancsnokság Hírszerző Részlege a Világháborúban 1914-1918.] B. u. C./126. 89.p.

- PETHÖ: op.cit. 58.p.

${ }^{31}$ ÖSA.KA. op.cit. Nachlässe und Sammlungen. [Hagyatékok és gyüjtemények.] Nachlaß Ronge. [RongE hagyaték.] Nachrichtenabteilung des Armmeoberkommandos im Weltkrieg 1914-1918. [A Szárazföldi Haderő Főparancsnokság Hírszerző Részlege a Világháborúban 1914-1918.] B. u. C./126. 41.p.

${ }^{32}$ Loc.cit. 53.p. + 61.p.

${ }^{33}$ REGELE: 80.p. ; SCHÄTZ: 93.p.

${ }^{34}$ ÖSA.KA. op.cit. Nachlässe und Sammlungen. [Hagyatékok és gyüjtemények.] Nachlaß Ronge. [RoNGE hagyaték.] Nachrichtenabteilung des Armmeoberkommandos im Weltkrieg 1914-1918. [A Szárazföldi Haderő Főparancsnokság Hírszerző Részlege a Világháborúban 1914-1918.] B. u. C./126. 14.p.

${ }^{35}$ ZEINAR: op.cit. 560.p.

${ }^{36}$ HHStA. Schaffung einer Zentralstelle für den defensiven Kundschafterdienst [Az elhárító szolgálat központi állomásának felállítása.] NA Nr. 8900 von 1917. Gliederung der NA. AOK. PA XL Interna Karton 241 Liasse II/4.

37 - KA AOK Faszikel 77 Karton 46 ex 1916.

- HÜTTERER: 30. p.

38 - ÖSA.KA. op.cit. Nachlässe und Sammlungen. [Hagyatékok és gyüjtemények.] Nachlaß Ronge. [RoNGE hagyaték.] Nachrichtenabteilung des Armmeoberkommandos im Weltkrieg 1914-1918. [A Szárazföldi Haderő Főparancsnokság Hírszerző Részlege a Világháborúban 1914-1918.] B. u. C./126. 48.p.

- РЕTHÖ: op.cit. 129-130.p.

- ZEINAR: op.cit. 560.p.

\section{Forrás- és irodalomjegyzék (a jegyzetekben alkalmazott röviditések oldása):}

\section{MONOGRÁFIÁK KISMONOGRÁFIÁK ÉS HASONLÓ JELLEGÜ KÖTETEK}

MORITZ — LEIDINGER — JAG
(14.;)
PETHÖ
(3.;6.;11.;12.;13.;21.;23.;26.;
27.;30.;38.;)
POKORNY
(5.;9.;16.;18.;20.;)
REGELE
(33.;)

RONGE

$(2 . ; 8 . ; 22 . ; 23 . ;)$

SCHEER

(4.;)
MoRITZ Verena — LEIDINGER Hannes — JAGSCHITZ Gerhard: Im Zentrum der Macht. Die vielen Gesichter des Geheimdienstchefs Maximilan Ronge. [A hatalom középpontjában. A titkosszolgálat fönökének, Maximilian RONGE-nek sok arca.] Bécs, 2007, Residenz Verlag. AT-ISBN 97837017 30844.

PETHÖ Albert: Agenten für den Doppeladler. Österreich-Ungarns Geheimer Dienst im Weltkrieg. [A kétfejü sas ügynökei. Osztrák-magyar titkosszolgálat a világháborúban.] Graz, 1998, Leopold Stocker Verlag. 875 p. AT-ISBN 9783705774159.

POKORNY Hermann: Emlékeim, a láthatatlan hírszerzö. Budapest - Kalocsa, 2000, Petit Real - Kaloprint. 168 p. HU-ISBN 963926703 1. /Hadtörténeti Levéltári Kiadványok./ HU-ISSN 1417-9598.

RegELE Oskar: Generalsatbchefs aus vier Jahrhunderten. Das Amt des Chefs des Generalstabes in der Donaumonarchie. Seine Trager und Organe von 1529 bis 1918. [Négy évszázad vezérkari fönökei. A dunai monarchia vezérkari fönökeinek hivatala és támogató szervezetei 1529-1918.] Bécs, 1966, Verlag Herold. 128 p.

- Ronge Maximilian: Kriegs- und Industriespionage. Zwölf Jahre Kundschaftsdienst. [Háború és ipari kémkedés. 12 év hírszerzőszolgálat.] Zürich-Leipzig-Bécs, 1930, Amalthea-Verlag. 384. p.

SCHEER Tamara: Die Ringstraßenfront. Österreich-Ungarn, das Kriegsüberwachungsamt und der Ausnahmezustand während des Ersten Weltkriegs. [A körútak frontja. Ausztria-Magyarország háborús biztonsági hivatala és vészhelyzet az I. világháború idején.] Bécs, 2010, Heeresgeschichtliches Museum. 210 p. AT-ISBN 9783902551160. 
URBANSKI

(13.;)

ZEINAR

$(21 . ; 35 . ; 38 . ;)$

\section{TANULMÁNYOK}

REIFBERGER

(3.;)
UrbanSKi August von Ostrymiecz: Das Evidenzbureau des k. u. k. Generalstabes. Ein Kommentar zu Generalmajor Max Ronge Werk „Kriegs und Industriespionage”. [A császári és királyi vezérkar Nyilvántartó Irodája. Kommentár Max Ronge vezérőrnagy „Háborús és ipari kémkedés” címü müvéhez.] 1930, Militärwissenschaftliche Mitteilungen.

- ZeInAR Hubert: Geschichte des österreichischen Generalstabes. [Az osztrák vezérkar története.], Bécs-Köln-Weimar, 2006, Böhlau. 868 p. ATISBN 9783205774150.

- Reifberger Josef: Die Entwicklung des militärischen Nachrichtenwesens in der k. u. k. Armee. [A császári és királyi haderő katonai felderítő szolgálatának fejlődése.] Österreichische Militärische Zeitschrift [Osztrák katonaújság], CLXVIII.évf. (1976) 3.sz. 213-223.p. AT-ISSN 00481444.

\section{LEVÉL-, IRAT- ÉS DOKUMENTUMTÁRI GYÜJTEMÉNYEK}

HHStA

(26.;36.;)

KA.AOK.

(37.;)

KA.NS.

(15.;)

ÖSA.KA.

(1.;2.;3.;5.;6.;7.;8.;10.;11.;12.;17.; $19 . ; 21 . ; 24 . ; 25 . ; 27 . ; 28 . ; 29 . ; 30 . ; 31 . ;$ 32.;34.;38.;)

\section{KÉZIRATOK}

HÜTTERER

(37.;)

SCHÄTZ

$(13 . ; 33 . ;)$
— Haus- Hof- und Staatsarchiv [Házi-, Udvari- és Állami Levéltár]

- Kriegs-archiv Armeeoberkommandos convulutum. [A Hadi Levéltár hadsereg- főparancsnoksági iratok gyüjteménye.]

- Kriegs-archiv Nachlässe und Sammlungen convulutum [A Hadi Levéltár Hagyatékai és Gyüjteményei.]

— Österreichisches Staatsarchiv. [Osztrák Állami Levéltár] Kriegsarchiv. [Hadilevéltár]

- HütTerer, Christine: Der Nachrichtendienst des k. u. k. Armeekommando von 1914-1918 mit besonderer Berücksichtigung der italienischen Kriegsgefangenen-und Überläuferaussagen an der Tiroler Front. [A Császári és Királyi Hadsereg-fóparancsnokság felderítő szolgálata 1914-1918. Különös tekintettel a tiroli front olasz hadifogolyainak és dezertöreinek a nyilatkozataira.] Disszertáció. Bécsi Egyetem, 1970. 326 p.

- SCHÄTZ, Angelika Maria: Nachrichtendienste in der österreichischen Rechtsentwicklung. [Felderítő szolgálat az osztrák jogfejlődésben.] Egyetemi disszertáció. Bécs, 1999.

\section{Mellékletek jegyzéke:}

I.sz. melléklet

Oskar von HraniloviC-CveTASSIN

II.sz. melléklet

Maximilian RoNGE 


\section{Oskar von HRANILOVIC-CVETASSIN} $(1867-1933)$

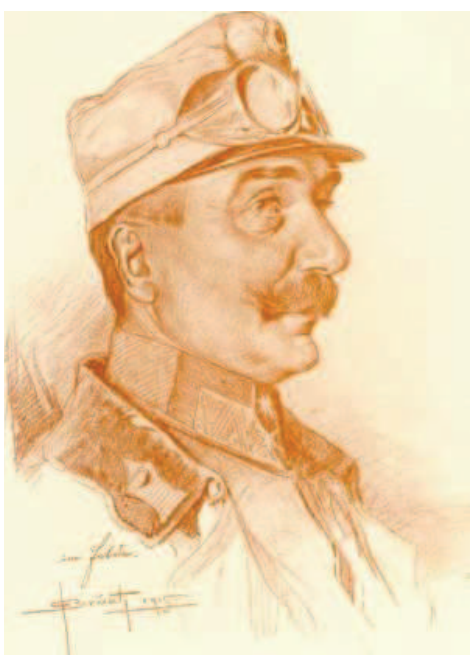

Az Osztrák-Magyar Monarchia hírszerzését irányította, a szervezet élére kerülésekor ezredesi rendfokozatban 1914-1917 között.

Forrás ! - Moritz Verena - LeIDINGER Hannes - JAGSCHITZ Gerhard: Im Zentrum der Macht. Die vielen Gesichter des Geheimdienstchefs Maximilian Ronge. [A hatalom középpontjában. A titkosszolgálat fönökének Maximilian Ronge-nak sok arca.] Wien, 2007, Residenz-Verlag. A-ISBN 9783701730384.

- PEтHÖ Albert: Agenten für den Doppeladler. Österreich-Ungarns Geheimer Dienst im Weltkrieg. [A kétfejű sas ügynökei. Az osztrák-magyar titkosszolgálat a világháborúban.] Graz, 1998, Leopold Stocker Verlag. A-ISBN 3702008306.

\section{Maximilian RoNGE}

II.sz. melléklet (1874. XI. 9. - 1953. IX. 10.)

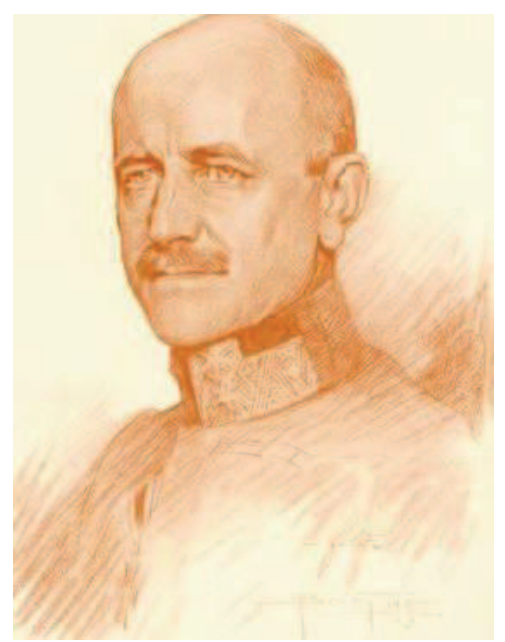

Az Osztrák-Magyar Monarchia hírszerzését irányította, a szervezet élére kerülésekor ezredesi rendfokozatban 1917-1919 között.

Forrás ! - Moritz Verena - Leidinger Hannes - JAGSChitz Gerhard: Im Zentrum der Macht. Die vielen Gesichter des Geheimdienstchefs Maximilian Ronge. [A hatalom középpontjában. A titkosszolgálat fönökének Maximilian Ronge-nak sok arca.] Wien, 2007, Residenz-Verlag. A-ISBN 9783701730384.

- PЕтHÖ Albert: Agenten für den Doppeladler. Österreich-Ungarns Geheimer Dienst im Weltkrieg. [A kétfejű sas ügynökei. Az osztrák-magyar titkosszolgálat a világháborúban.] Graz, 1998, Leopold Stocker Verlag. A-ISBN 3702008306. 